\title{
Bioactive Peptides Derived from Fish By-Product Collagen
}

\author{
Armin Mirzapour Kouhdasht ${ }^{1}$ and Marzieh Moosavi-Nasab ${ }^{2,3 *}$ \\ ${ }^{1}$ Department of Food Science and Technology, Student of Food Biotechnology, School of Agriculture, Shiraz University, Iran \\ ${ }^{2}$ Seafood Processing Research Group, School of Agriculture, Shiraz University, Iran \\ ${ }^{3}$ Department of Food Science and Technology, School of Agriculture, Shiraz University, Iran
}

Submission: June 12, 2018; Published: July 16, 2018

*Corresponding author: Armin Mirzapour Kouhdasht, Department of Food Science and Technology, Student of Food Biotechnology, School of Agriculture, Shiraz University, Iran, Email: armin.mirzapour@shirazu.ac.ir

\section{Abstract}

The mismanagement of the fish processing industry has led to a lot of waste generation around the world, which contains a large amount of organic compounds. This massive amount of by-products is a major problem for both manufacturers and the environment. The exploitation of these by-products to produce functional biomolecule has become an essential demand. One of these biomolecules are collagen bioactive peptides derived from by-products. Many biological activities of peptides have been studied so far including antioxidant, antimicrobial, antihypertensive, anti-inflammatory, dipeptidyl-peptidase IV (DPP-IV) inhibitory, and etc. This study focuses on the main sources of collagen in fish by-products, the production of bioactive peptides from this collagen, and some biological activities of them.

Keywords: Collagen; Bioactive Peptides; Fish Collagen; By-Products

\section{Introduction}

Fish industries are one of the most important factors affecting the economy of many countries around the world. Fish processing by-products, Substances that remain after the primary processing of the fish, are an immense part of manufacturing the fishes He et al. [1]. The massive amount of by-products (over than $60 \%$ of total biomass) is a major ecological and economical problem. The question is what to do with the increasing amount of by-products. A solution has to be found to prevent disposing of these by-products and they should be exploited as raw materials for the production of value added molecules, instead of being discarded Morales-Medina et al. [2]. The protein content is about 8 to $35 \%$ and this amount is approximately 10 to $20 \%(\mathrm{w} / \mathrm{w})$ of total content of whole fish Sila and Bougatef [3]. Fish by-products comprise a large amount of collagen, which is a value added row material for bioactive peptides. Fish by-product gelatin (soluble collagen) have privileges including high availability, lack of disease transmission risk, no religious restrictions, and high yields Senaratne Park \& Kim [4] Over the last two decade, many researchers have notices the generation of bioactive peptides by enzymatic hydrolysis of collagen. The Pro residues at the C-terminal tripeptide region of a peptide has been associated with a positive effect on their angiotensin converting enzyme (ACE) inhibitor potential Stepaniak \& Sørhaug [5], and we know that the collagen is a good source of this imino acid which could be used for production of such tripe prides. These peptides have a potential to act as natural alternatives for synthetic drugs or supplements to functional foods.

\section{Collagen from Fish Processing By-product}

Recently, collagen (a raw material for production of bioactive peptides) from fish processing by-products has received significant attention. Fish processing by-products play an important role as sources of value added compounds such as collagen, gelatin, amino acids, oils, and enzymes Ghaly et al. [6]. The major collagen constituent of fishby-productis in skins, scales, bones, and swim bladder Eastoe [7], Giraud-Guille et al. [8].

\section{Bioactive Peptides Extraction from Collagen}

Nowadays, two major procedures for the production of collagen hydrolysates in industrial and analytical practices are biological and chemical methods. Chemical method involves acid and/or alkaline for hydrolysis of collagen structure. This method is inexpensive and easy to perform so it has been used preferably and extensively to produce collagen hydrolysates at industrial scale. However, in this method, due to severe conditions and non-specific cleavage of peptide bonds, the process cannot be controlled, resulting in lack of homogeneity and reduction of nutritional quality of produced peptides. On the other hand, biological method (enzymatic hydrolysis) involves the mild and specific cleavage of proteins (collagen in 
this case) by proteolytic enzymes (collagenases) Celus et al. [9]. Collagenases are the matrix metalloproteases (MMPs)capable to hydrolysis the collagen. As a result ofadamant triple helical structure collagensresist against the typical proteases but not by sitespecific action of MMPs (Figure 1) Pal and Suresh [10]. Physicochemical conditions (temperature, $\mathrm{pH}$, and enzyme/ substrate ratio) must be optimize for the hydrolysis reaction (Kim and Wijesekara [11]; Santos et al. [12]. When the reaction was done, it is crucial to inactivate the enzyme by heating the (85$95{ }^{\circ} \mathrm{C}$ for $5-20 \mathrm{~min}$ ) or acidifying the hydrolysate mixture. This step (termination of hydrolysis) can be coupled to membrane technology to decrease the costs Guerard [13]. Subsequently, hydrolyzed proteins (peptides) must be separated and purified as different fractions by chromatography methods and identified by mass spectrometry analysis Harnedy et al. [14].

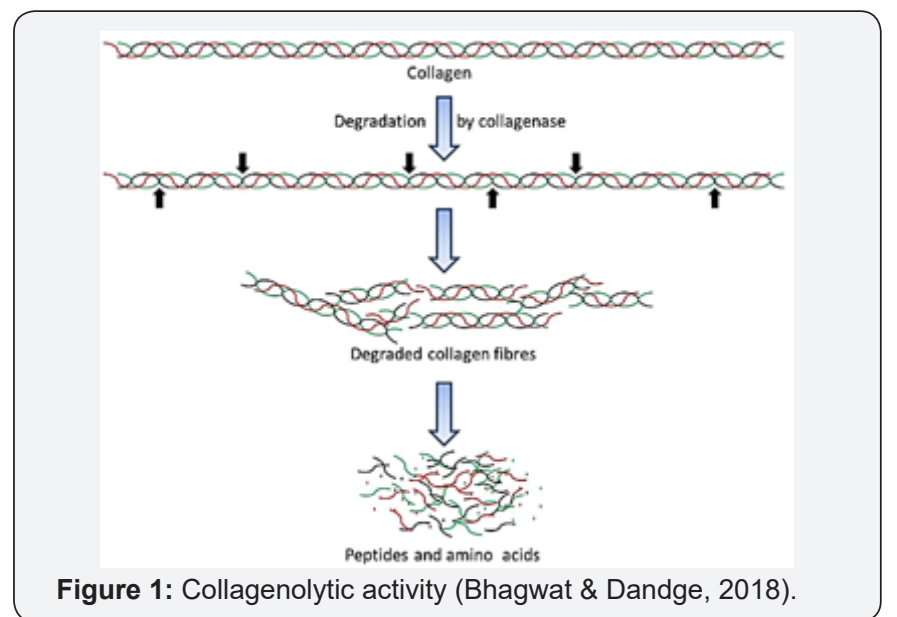

Biological Activities of Peptides

Antimicrobial Activity: Antimicrobial peptides (AMPs) are actually sequences of amino acids containing less than 50 amino acids which are predominantly hydrophobic Najafian and Babji [15]. The antibacterial activity mechanism of these peptides is due to the interaction with cell membrane and form pores or block the membrane ion gradients leading to the cell destruction. However, another mechanism has been observed by which peptides because a cell deficiency apparently by making changes in the cellular metabolism Wald et al. [16]. All reports of AMPs isolated from fish collagen have demonstrated antibacterial activities against Gram-negative and Gram-positive bacteria. Thus they can be a novel substitution for antibiotics. Anti microbial activity of these collagen peptides is a broad spectrum characteristic which includes antibacterial, antiviral, antifungal, immune modulator, and antitumor agents Kim and Wijesekara [11]; Rajanbabu and Chen [17].

Antioxidant Activity: A profitable effect of bioactive peptides derived from fish processing by-products collagen is antioxidant activity which are found in several ways, including the scavenging free radicals and reactive oxygen species (ROS) Krisetherton et al. [18] High concentrations of ROS can be excessively destructive for cells and it will happen when their concentration outpace the scavenging capacity Amado et al. [19]. It has been demonstrated by some researchers that the hydrophobic amino acids (alanine, phenylalanine, isoleucine, leucine, valine, glycine, proline, methionine, tyrosine, histidine, lysine, and cysteine), acidic amino acids (glutamic acid and aspartic acid) and basic amino acids (arginine, lysine, and histidine), and finally aromatic residues probably enhance the antioxidant activity of bioactive peptides due to their potential to act as proton donors or electron and/or as lipid radicals scavengers Je et al. [20]; Samaranayaka and Li-Chan[21]; Sarmadi and Ismail [22], chelator of metal ions as a result of presence of carboxyl and amino groups in the side chains Udenigwe and Aluko [23], and proton donors to radicals with electron.

Antihypertensive activity: One of the most investigated characteristics of bioactive peptides from collagen is angiotensin converting enzyme (ACE) I inhibitory activity. Angiotensin I which is a decapeptide converts by ACE (EC 3.4.15.1, di carboxy peptidase) to potent vasoconstrictor Angiotensin II. Thus, it has been demonstrated that the inhibition of this enzyme plays a crucial role in the prevention of hypertension. Updated research (Bader and Ganten [24]. In a specialized article by Yi et al. [25] it has been demonstrated that bioactive peptides can be achieved from grass carp skin collagen by Alcalase, collagenase, proteinase $\mathrm{k}$ and/or trypsin at their optimum conditions. They also mentioned that Alcalase and collagenase completely hydrolyzed the raw material and released peptides with ACE-inhibitory activity and this activity increased linearly with increasing degree of hydrolysis. Another study by Cheung and Li-Chan ACE-inhibitory peptides were produced from steel head (Oncorhynchusmykiss) skin gelatin using proteolytic enzymes acting either individually or sequentially on substrate. Fractions with low molecular weight $(<3 \mathrm{kDa})$ separated by UF filtration showed strong ACE-inhibitory activity. Their results demonstrated that particularly, hydrolysates produced using $4 \%$ papain for $2 \mathrm{~h}$ followed either by ultra filtration or by a second hydrolysis with $1 \%$ Corolase $\mathrm{N}$ for $2 \mathrm{~h}$, presented potent ACEinhibitory activity.

Other Functional Characteristics: There are lots of different biological activities that are attributed to collagen hydrolysates from fish processing by-products. So these peptides are promising ingredients for functional foods and nutraceuticals. One of important applications of collagen peptides derived from fish processing by-products is targeting the calmodulin ( $\mathrm{CaM}$ ), a protein for sustaining physiological activities of body cells and organs Cho et al. [26]. Calcium - dependent cell division, cell proliferation, and neurotransmission are some functions of this multifunctional protein Veigel et al. [27]; Rasmussen and Means [28]). However, extra amount of CaM may causechronic diseases like cancer (Hait and Lazo, [29], O’Day and Myre [30] Obata et al. [31]). Therefore, biological peptides can be exploited to prevent or treat in such conditions. The anti-proliferation activity of these peptides has been proved and demonstrates a correlation with antioxidant activities. It has not been reported in any research that there is a relationship between the peptides molecular weight and their anti-proliferation activity Hsu et al. 
[32] Hung et al. [33] Lee et al. [34]. Protein hydrolysates isolated from salmon frame and tilapia skin gelatin have demonstrated antidiabetic activity Roblet et al. [35] Wang et al. [36]. An outstanding research by Li-Chan and coworker was mentioned above. All the fractions of bioactive peptides from steelhead skin gelatin which have showed high ACE-inhibitory activity, were also antidiabetic as they showed high DPPIV inhibitory activity $[37,38]$.

\section{Conclusion}

We tried to briefly illustrate a general perspective of collagen bioactive peptides derived from fish processing byproducts. Functional peptides are now agreat sector within the nutraceutical. Technological and basic complications are related to scale up the production process, congeniality with food constituents, stability in gastrointestinal (GI) tract, bioavailability, and safety along the time. Despite the fact that many studies have been conducted about biological active peptides, but there is still a need for more researches to be done to determine all the aspects in this field.

\section{References}

1. He S, Franco C, Zhang W (2013) Functions, applications and production of protein hydrolysates from fish processing co-products (FPCP). Food Research International 50(1): 289-297.

2. Morales Medina R, Tamm F, Guadix AM, Guadix EM, Drusch S (2016) Functional and antioxidant properties of hydrolysates of sardine (S. pilchardus) and horse mackerel (Tmediterraneus) for the microencapsulation of fish oil by spray-drying. Food Chemistry 194: 1208-1216.

3. Sila A, Bougatef A (2016) Antioxidant peptides from marine byproducts: Isolation, identification and application in food systems: A review. Journal of Functional Foods 21: 10-26.

4. Senaratne LS, Park PJ, Kim SK (2006) Isolation and characterization of collagen from brown backed toadfish (Lagocephalusgloveri) skin. Bioresource Technology 97(2): 191-197.

5. Pripp A, Isaksson T, Stepaniak L, Sørhaug T (2004) Quantitative structure activity relationship modelling of ACE-inhibitory peptides derived from milk proteins. European Food Research and Technology 219: 579-583.

6. Ghaly AE, Ramakrishnan VV, Brooks MS, Budge SM, Dave D (2013) Fish processing wastes as a potential source of proteins, amino acids and oils: a critical review. Journal of Microbial Biochemical Technology 5: 107-129.

7. Eastoe JE (1957) The amino acid composition of fish collagen and gelatin. Biochemical Journal 65(2): 363-368.

8. Giraud Guille MM, Besseau L, Chopin C, Durand P, Herbage D (2000) Structural aspects of fish skin collagen which forms ordered arrays via liquid crystalline states. Biomaterials 21(9): 899-906'.

9. Celus I, Brijs K, Delcour JA (2007) Enzymatic hydrolysis of brewers' spent grain proteins and techno functional properties of the resulting hydrolysates. Journal of Agricultural and Food Chemistry 55(21): 8703-8710.

10. Pal GK, Suresh PV (2016) Microbial collagenases: challenges and prospects in production and potential applications in food and nutrition. RSC Advances 6: 33763-33780.

11. Kim SK, Wijesekara I (2010) Development and biological activities of marine-derived bioactive peptides: a review. Journal of Functional
Foods 2(1): 1-9.

12. Santos SD, Martins VG, Salas Mellado M, Prentice C (2011) Evaluation of functional properties in protein hydrolysates from bluewingsearobin (Prionotus punctatus) obtained with different microbial enzymes. Food Bioprocess Technology 4: 1399-1406.

13. Guerard F (2007) Maximising the value of marine by-products. Cambridge, Woodhead Publishing Ltd.

14. Harnedy PA, OKeeffe MB, FitzGerald RJ (2017) Fractionation and identification of antioxidant peptides from an enzymatically hydrolysed Palmariapalmata protein isolate. Food Research International 100 416-422.

15. Najafian L, Babji AS (2012) A review of fish-derived antioxidant and antimicrobial peptides: their production, assessment, and applications. Peptides 33(1): 178-185.

16. Wald M, Schwarz K, Rehbein H, Bubmann B, Beermann C (2016) Detection of antibacterial activity of an enzymatic hydrolysate generated by processing rainbow trout by-products with trout pepsin. Food Chemistry 205: 221-228.

17. Rajanbabu V, Chen JY (2011) Applications of antimicrobial peptides from fish and perspectives for the future. Peptides 32: 415-420.

18. Kris etherton PM, Hecker KD, Bonanome A, Coval SM, Binkoski AE, et al. (2002) Bioactive compounds in foods: Their role in the prevention of cardiovascular disease and cancer. The American Journal of Medicine 113: 71-88.

19. Amado LL, Garcia ML, Ramos PB, Freitas RF, Zafalon B (2009) A method to measure total antioxidant capacity against peroxyl radicals in aquatic organisms: application to evaluate microcystins toxicity. Science of the Total Environment 407: 2115-2123.

20. Je JY, Qian ZJ, Byun HG, Kim SK (2007) Purification and characterization of an antioxidant peptide obtained from tuna backbone protein by enzymatic hydrolysis. Process Biochemistry 42(5): 840-846.

21. Samaranayaka AG, Li Chan EC (2011) Food derived peptidic antioxidants: A review of their production, assessment, and potential applications. Journal of functional foods 3: 229-254.

22. Sarmadi BH, Ismail A (2010) Antioxidative peptides from food proteins: A review. Peptides 31 (10): 1949-1956.

23. Udenigwe CC, Aluko RE (2012) Food protein derived bioactive peptides: Production, processing, and potential health benefits. Journal of Food Science 77(1): 11-24.

24. Bader M, Ganten D (2008) Update on tissue renin-angiotensin systems. Journal of Molecular Medicine 86(6): 615-621.

25. Yi J, De Gobba C, Skibsted LH, Otte J (2017) Angiotensin-I converting enzyme inhibitory and antioxidant activity of bioactive peptides produced by enzymatic hydrolysis of skin from grass carp (Ctenopharyngodonidella) International Journal of Food Properties 20: $1129-1144$.

26. Cho MJ, Vaghy PL, Kondo R, Lee SH, Davis JP, et al. (1998) Reciprocal regulation of mammalian nitric oxide synthase and calcineurin by plant calmodulin isoforms. Biochemistry 37(45): 15593-15597.

27. Veigl ML, Vanaman TC, Sedwick WD (1984) Calcium and calmodulin in cell growth and transformation. BiochimicaetBiophysicaActa (BBA)Reviews on Cancer 738: 21-48.

28. Rasmussen CD, Means AR (1987) Calmodulin is involved in regulation of cell proliferation. The EMBO Journal 6: 3961-3968.

29. Hait WN, Lazo JS (1986) Calmodulin: A potential target for cancer chemotherapeutic agents. Journal of Clinical Oncology 4(6): 994-1012.

30. O Day DH, Myre MA (2004) Calmodulin-binding domains in Alzheimer's disease proteins: extending the calcium hypothesis. Biochemical and biophysical research communications 320: 1051-1054. 
31. Obata K, Nagata K, Iwase M, Odashima M, Nagasaka T, et al. (2005) Overexpression of calmodulin induces cardiac hypertrophy by a calcineurin-dependent pathway. Biochemical and biophysical research communications 338: 1299-1305.

32. Hsu KC, Li Chan EC, Jao CL (2011) Antiproliferative activity of peptides prepared from enzymatic hydrolysates of tuna dark muscle on human breast cancer cell line MCF-7. Food Chemistry 126(2): 617-622.

33. Hung CC, Yang YH, Kuo PF, Hsu KC (2014) Protein hydrolysates from tuna cooking juice inhibit cell growth and induce apoptosis of human breast cancer cell line MCF-7. Journal of Functional Foods 11: 563-570.

34. Lee SH, Lee MY, Kang HM, Han DC, Son KH, et al. (2003) Anti tumor activity of the farnesyl-protein transferase inhibitors arteminolides, isolated from Artemisa. Bioorganic \& Medicinal Chemistry 11: 45454549 .

This work is licensed under Creative Commons Attribution 4.0 License

DOI: 10.19080/IJESNR.2018.13.555859
35. Roblet C, Akhtar MJ, Mikhaylin S, Pilon G, Gill T, et al. (2016) Enhancement of glucose uptake in muscular cell by peptide fractions separated by electrodialysis with filtration membrane from salmon frame protein hydrolysate. Journal of Functional Foods 22: 337-346.

36. Wang TY, Hsieh CH, Hung CC, Jao CL, Chen MC, et al. (2015) Fish skin gelatin hydrolysates as dipeptidyl peptidase IV inhibitors and glucagon like peptide 1 stimulators improve glycaemic control in diabetic rats: A comparison between warm and coldwater fish. Journal of Functional Foods 19: 330-340.

37. Bhagwat PK, Dandge PB (2018) Collagen and collagenolytic proteases: A review. Bio catalysis and Agricultural Biotechnology 15: 43-55.

38. He S, Franco C, Zhang W (2013) Functions, applications and production of protein hydrolysates from fish processing co-products (FPCP). Food Research International 50(1): 289-297.

\section{Your next submission with Juniper Publishers will reach you the below assets}

- Quality Editorial service

- Swift Peer Review

- Reprints availability

- E-prints Service

- Manuscript Podcast for convenient understanding

- Global attainment for your research

- Manuscript accessibility in different formats

( Pdf, E-pub, Full Text, Audio)

- Unceasing customer service

Track the below URL for one-step submission https://juniperpublishers.com/online-submission.php 